\title{
MORFOLOGI ARSITEKTUR DAN TRANSFORMASI FISIK MASJID AGUNG LAMONGAN
}

\author{
Hammam Rofiqi Agustapraja ${ }^{1}$, Yulistia Maulidina ${ }^{2}$ \\ ${ }^{1,2}$ Program Studi Teknik Sipil, Fakultas Teknik, Universitas Islam Lamongan \\ $J l$ Veteran 53A Lamongan, 62211 \\ hammamrofigi@unisla.ac.id
}

\begin{abstract}
The Great Mosque of Lamongan as a cultural asset in Lamongan has experienced many developments, expansions, and changes in physical form, especially in the facade which is the outward appearance of a building. In this study, there are problems with the morphological approach and physical transformation in the Great Mosque of Lamongan based on the incorporation of a typology of the facade into new formations?. The method in this study with descriptive analysis in the manifestation of the change in the form of the Lamongan Great Mosque facade from time to time, then the approach used is a historical approach. From this approach, the physical changes are analyzed according to the style (typology) of the existing Mosque Architecture typology. The results of this study state that the merging of forms between the characteristics of universality and locality results in a dynamic formation with local characteristics.
\end{abstract}

Keywords: Lamongan Great Mosque, Architectural Morphology, Facade Transformation

\section{PENDAHULUAN}

Perkembangan Masjid Agung Lamongan, semakin pesat, terutama pada tahun 2000an, yang membuat tampilan fisik Masjid ini berubah secara drastis, adanya pembangunan dua menara kembar yang menjulang tinggi, dan fasad utama masjid yang berbeda dengan tampilan masjid pada umumnya.

Masjid Agung Lamongan berdiri pada tahun 1908, terletak di pusat Kota Lamongan, yaitu berada di Jalan KH. Hasyim Asyari, atau berada di sebelah barat Alun-Alun Kota Lamongan. Dengan perkembangan ini maka peneliti memiliki rumusan masalah yang perlu dikaji dan dibahas dalam penelitian ini yaitu bagaimana pendekatan morfologi dan transformasi fisik pada Masjid Agung Lamongan berdasarkan penggabungan tipologi fasad menjadi bentukan-bentukan baru.

Tujuan dari penelitian ini ialah untuk mengetahui proses transformasi bentuk fisik pada tipologi fasade Masjid Agung Lamongan, dalam menggabungkan ciri universalitas dan lokalitas sekaligus.

Untuk menjawab masalah dan sesuai dengan tujuan penelitian maka dapat dijelaskan beberapa teori dari penelitian-penelitian sebelumnya yang mengatakan bahwa morfologi dilihat dari pengertian harfiah, morfologi berarti 'pengetahuan tentang bentuk' (morphos), sedangkan pengertian dari Morfologi arsitektur lebih menekankan pada pembahasan bentuk-bentuk geometrik, sehingga dalam menentukan nilai ruang dikaitkan dengan maksud ruangan tersebut. Sehingga dari keterkaitan ini kita bisa melihat keterkaitan yang erat antara organisasi ruang, hubungan ruang, bentuk ruang dan nilai ruang. (Amarullah, 2014).
Penelitian morfologi digunakan pendekatan genetik morfologis yang ditujukan untuk memperoleh gambaran tentang perkembangan bentuk satuan objek arsitektur masjid, sejak awal kehadiran sampai bentuk terakhir bersifat sinkronik, karena bertujuan menemukan variasi/ragam fenomena/fakta yang ada pada saat sekarang, namun masih mengacu pada bentukan pada masa lalu sehingga nantinya dapat diambil nilai-nilai sejarahnya yang bisa dilestarikan dan dipertahankan.

Menurut Rochym (1983) dalam Ayun (2015), masjid merupakan sebuah perwujudan kebudayaan dan pusat kegiatan Islam, secara arsitektural. Maka kemudian, tampillah arsitektur masjid secara bervariasi,yang dipengaruhi oleh periode waktu, serta lokasi dimana ia didirikan. Hal ini disebabkan karenaterdapat unsur adat kebiasaan danlatar belakang manusia yang menciptakannya. Oleh karena itu, pada dasarnya setiap daerah di kawasan regional tertentu, telah memiliki morfologi dan bentuk dasar tipologi masjid dengan karakter yang khusus.

\section{METODE}

Metode yang digunakan ialah metode deskriptif analisis dengan cara pengamatan dan pemaparan kondisi, dengan mendeskripsikan dan menganalisa fenomena yang diteliti secara sistematis, faktual dan akurat. Dalam pengejawantahan proses transformasi bentuk fisik dari fasade Masjid Agung Lamongan ini melibatkan perubahan -perubahan dari waktu ke waktu, maka pedekatan yang digunakan ialah pendekatan historis. Dari pendekatan tersebut perubahan fisiknya di analisis menurut langgam (style) tipologi Arsitektur Masjid yang ada. 


\section{PEMBAHASAN}

3.1 Transformasi bentuk Fisik Masjid Agung Lamongan

Masjid Agung Lamongan ini dibangun dengan beberapa tahap, hal tersebut dipengaruhi oleh beberapa faktor termasuk sosial ekonomi pada saat itu. Beberapa tahapan - tahapan pembangunan Masjid Agung Lamongan antara lain, sebagai berikut:

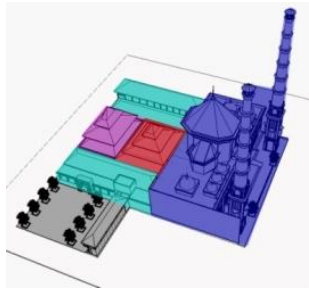

Gambar 1. Massa Masjid Agung Lamongan

1. bangunan masjid pertama

2. bangunan masjid kedua

3. bangunan masjid tambahan sisi timur, utara dan selatan

1908, Bangunan Masjid sangat sederhana, berdiri di atas tanah waqof, seiring berkembangnya waktu, yang dirasa sudah tidak bisa menampung jumlah jamaah yang sudah semakin banyak.

1919, Masyarakat memberikan amanah kepada KH. Mastor Asnawi selaku ulama besar di kota Lamongan yang sudah lama bermukim di makkah, untuk melakukan renovasi untuk pembangunan dan pengembangan Masjid Agung Lamongan.

Awal dilakukan pembangunan pandemen (tebing sungai) lama direnovasi dari yang berukuran $0.5 \mathrm{~m}$ menjadi $1.25 \mathrm{~m}$, sehingga tidak serasi dengan gapura. Hal tersebut dikarenakan letak Masjid yang berada di timur sungai, sehingga rawan terjadi banjir apabila tidak ditinggikan.

1922, Bangunan masjid kemudian dipugar dan letaknya sekarang bagian tengah masjid, dengan menggunakan struktur kayu, terdapat empat tiang soko guru sebagai penopang utamanya, yang terbuat dari kayu jati dan kolom kayu pendampingnya dengan modul setiap $\pm 3 \mathrm{~m}$. bangunan awal ini mempunyai luasan $\pm 380 \mathrm{~m} 2$, yang unik dari bangunan awal ini ada tangga ke atas, yang berfungsi sebagai tempat mengumandangkan adzan, dan bentuknya sekarang masih dipertahankan, walaupun sudah tidak terpakai lagi.

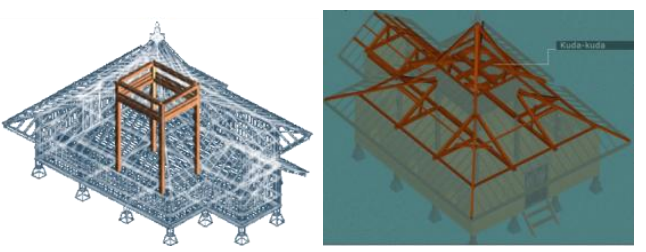

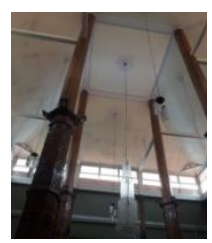

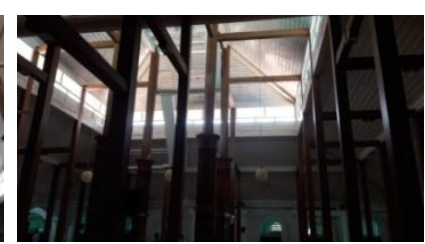

Gambar 2. Struktur Soko Guru Yang Dipakai Pada Masjid Utama

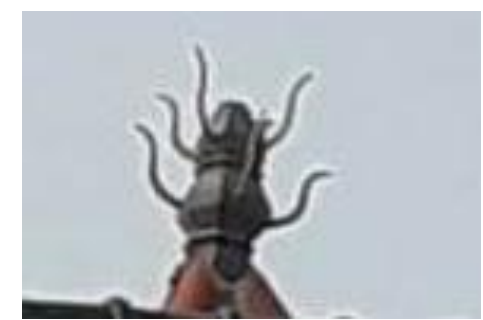

Gambar 3. Puncak Atap / Memolo Pada Bangunan Masjid Utama Masjid Agung Lamongan

Atap berupa piramida bertumpuk tiga, dengan penutup atap genting berwarna jingga ke coklatan, dan di puncak atapnya di beri mahkota atau yang disebut "memolo", terbuat dari logam, dan terdapat cabang-cabang yang bertingkat.

Pengembangan selanjutnya ke arah barat, dengan membangun bangunan yang sama dengan bangunan awal, termasuk luas, bentuk dan konstruksi yang digunakan. Di masjid pengembangan ini terdapat mihrab dan mimbar.
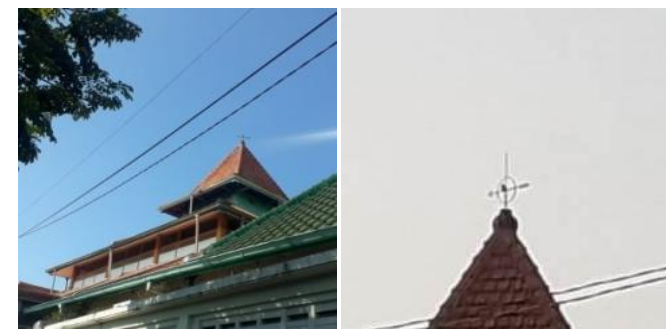

Gambar 4. Bentuk Atap Masjid Ke Dua Dengan Puncak Atap Berupa Penunjuk Arah Angin

Bentuk atapnya juga sama dengan bangunan pertama, dengan atap piramida bersusun dan penutup atap genting yang berwarna jingga kecoklatan, tetapi ada yang berbeda pada pucaknya, terdapat penunjuk angin (weathervane).

Bangunan Masjid pertama dan ke dua ini mengacu pada tipologi masjid-masjid tradisional di Jawa, salah satu acuan masjid tradisional ini adalah Masjid Demak, yang bercirikan atap lancip dan bersusun ganjil, pada umumnya bersusun tiga, yang disangga oleh struktur kayu Soko guru, di puncak atap terdapat mahkota atau yang disebut dengan "memolo" 


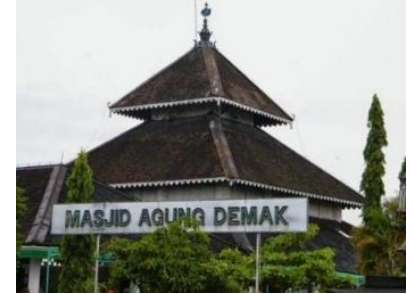

Gambar 5. Atap Masjid Agung Demak dengan Memolo

Sumber : http://bpad.jogjaprov.go.id

1970-an, dibangun menara, yang bentuknya menyerupai dengan menara Masjid Qiblatain yang ada di Madinah, Arab Saudi. Karena sang pendiri Masjid ini KH Mastur Asnawi lama bermukim di Arab Saudi, terutama di Madinah.

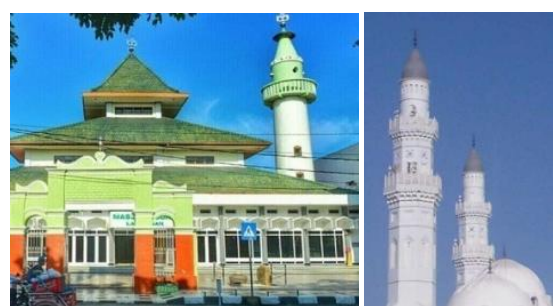

Gambar 6: Menara Qiblatain Masjid Agung Lamongan (kiri) dan Menara Masjid Qiblatain Madinah (kanan)

Sumber : ndiray.wordpress.com

Secara umum bentuk menara "Qiblatain" Masjid Agung Lamongan tidak sama dengan menara di Masjid Qiblatain, Madinah Arab Saudi, hanya terdapat persamaan bentuk pada puncak menara berbentuk kerucut, selebihnya termasuk badan dan ornamen tidak memiliki persamaan, hal tersebut dimungkinkan kendala biaya atau teknis sehingga bentuknya tidak sama persis.

1980-an, dilakukan pelebaran di sebelah utara dan timur, termasuk membangun bangunan 2 lantai. Pembangunan sebalah timur ini membuat menara dan komplek makam pendiri masjid yang awalnya di luar masjid menjadi di dalam ruangan.

Pembangunan ini diprakarsai oleh Yayasan Amal Bakti Muslim Pancasila, sebuah yayasan pada masa orde baru yang bergerak dibidang keagamaan terutama pada pengembangan masjid.

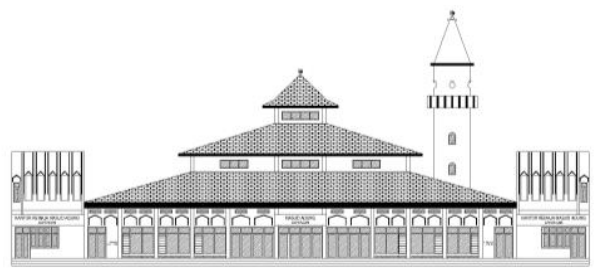

Gambar 7. Tampak Depan Serambi Timur Masjid Agung Lamongan

Bentuk penambahan bangunan tersebut berupa serambi masjid dengan atap susun tiga, menyesuaikan dengan bangunan masjid utama, dan di sisi kanan dan kiri dibangun bangunan 2 lantai yang berfungsi sebagai kantor dan fasilitas pendukung.

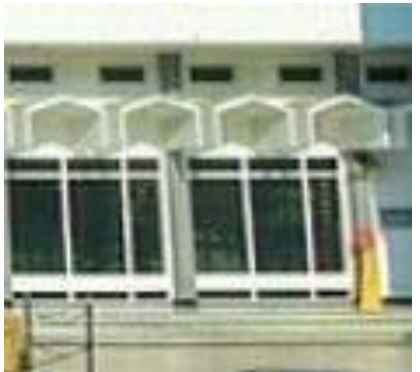

\section{Gambar 8. Bentuk Pintu, Jendela Dan Tritisan} Pada Bangunan Sisi Timur 1980-An

Bentukan bangunan tambahan ini secara garis besar sederhana tidak terlalu banyak menggunakan ornamen, bentukan jendelanya pun hanya berbentuk persegi dengan tritisan seperti segi enam yang terpotong, hal ini seperti tipologi dari bentukan masjid-masjid yang dibangun yayasan tersebut di seluruh Indonesia, geometrikal yang sederhana dan mengusung atap bersusun tiga pada struktur atapnya.

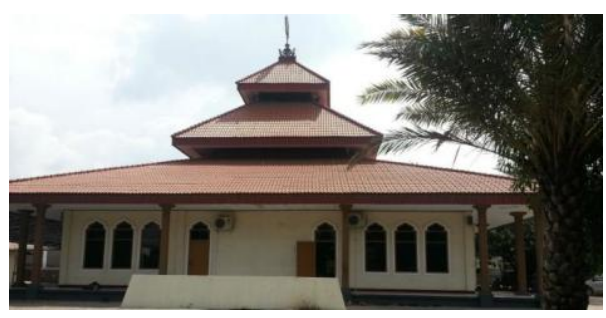

\section{Gambar 9. Salah Satu Masjid Yang Dibangun Yayasan Amal Bakti Muslim Pancasila Sumber : Bimasislam.kemenag.go.id}

2000-an, pengembangan Masjid Agung Lamongan mengacu pada perluasan sebelah selatan, karena ada pembebasan lahan di sisi selatan sehingga masjid bisa dapat di akses dari Jalan Basuki Rahmad.

Pembangunannya berupa gapura pintu masuk, lahan parkir. Tempat wudhu dan fasad sisi selatan yang disesuaikan dengan penambahan pintu-pintu dan gerbang utama sisi selatan. Gerbang tersebut berupa perpaduan geometri persegi dengan dipadukan lengkung kubah, perpaduan tersebut tipikal dari Arsitektur Mughal, yang berkembang pada abad 16-18 di India dan sekitarnya, sebagai masterpiece dari langgam arsitektur ini adalah Taj Mahal, bentuk pintu masuk utama pada bangunan ini juga perpaduan antara geomettrikal persegi dan lengkung kubah yang simetris. 

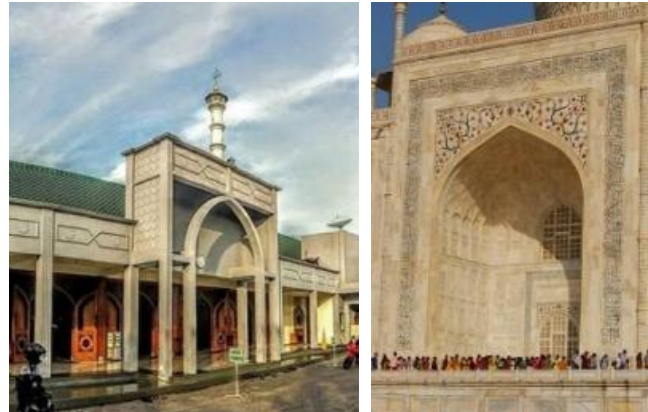

Gambar 10. Gerbang Sisi Selatan Masjid Agung Lamongan (Kiri) Dan Gerbang Utama Taj Mahal (Kanan)

Sumber : id.pinterest.com

2011, dibangun menara kembar dengan tinggi $53 \mathrm{~m}$, yang dinisbatkan kepada umur Nabi Muhammad ketika melakukan hijrah dari Makkah ke Madinah.

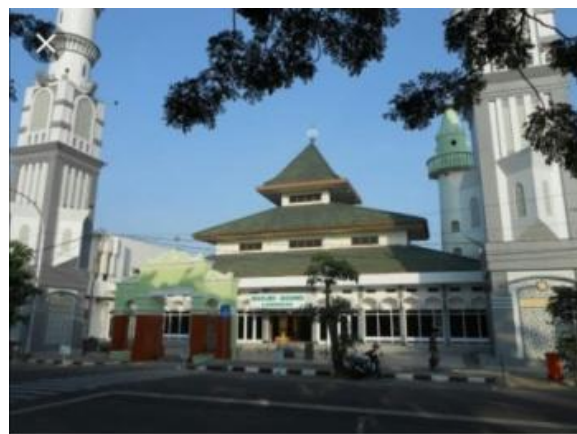

Gambar 11. Bangunan Sisi Timur Yang Diapit 2 Menara Kembar

Pembangunan 2 menara ini membuat bangunan serambi timur menjadi tenggelam karena beda ketinggian yang sangat signifikan, dan secara fasad bangunan sisi timur kurang sesuai dengan bentuk ornamentasi menara tersebut.

2018, dilakukan pemugaran bangunan sisi timur, dengan menyesuaikan langgam gaya arsitektur dengan menara kembar yang sudah ada, dan dilakukan pembongkaran terhadap gapura Masjid.

Bentukan 2 menara kembar ini seperti penempatan 2 menara di pintu masuk Masjidil Haram di Makah, Arab saudi, bentukan dari "kepala" menara Masjid Agung Lamongan memiliki kemiripan dengan menara Masjidil Haram, hanya mahkotanya yang berbeda, di Masjid Agung Lamongan memakai mahkota kaligrafi Allah, sedangkan di Makkah memakai bulan sabit. Sedangkan untuk badan menara tidaksama, Masjid Agung Lamongan terdapat ornamen sabuk sebanyak 5 buah, sedangkan di Makkah tidak ada.

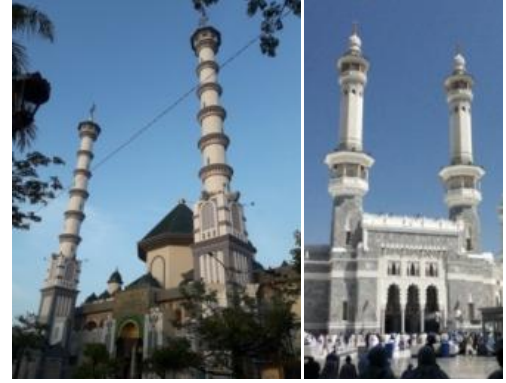

Gambar 12. Menara Masjid Agung Lamongan dan Menara Masjid Haram Makkah Sumber: tiatimki.wordpress.com

Untuk penutup atap utama pada bangunan baru sisi timur ini mempunyai kesamaan dengan langgam mediteranian di Eropa, hal tersebut diperkuat dengan kesamaan pada bentukan Masjid Agung di Paris, Perancis. Masjid Agung Paris yang dibangun 1922 dan diresmikan pada 15 Juli 1926 oleh Presiden Prancis Gaston Doumergue yang menjabat saat itu.

walaupun bisa dikatakan bentukan atap terssbut merupakan upaya untuk memberikan benang merah serial vision antara atap segitiga tradisional jawa dan bangunan baru modern, sehingga terjadi kesinambungan bentuk antara Masjid utama dan bangunan baru.
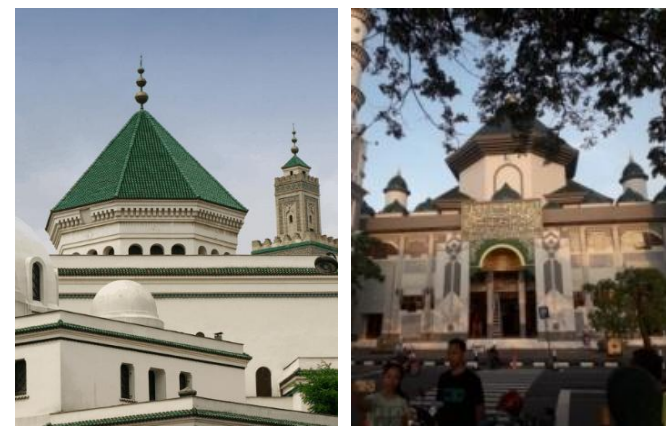

Gambar 13. Atap Masjid Agung Paris, Perancis (kanan) dan Atap Bangunan sisi Timur Masjid Agung Lamongan

Sumber : kontraktorkubahmasjid.com

Untuk ornamen pada pintu masuk utama, terdapat ornamen setengah kubah berwarna emas, ornamentasi tersebut terdapat pada langgam Masjid Phustun, yang berkembang di daerah Iran dan sekitarnya, kubah tersebut disebut "muqarnas" .

Yang membedakan dari kedua bentukan tersebut adalah, Pada Masjid Agung Lamongan kubah tersebut hanya berupa ornamentasi sedangkan "muuqarnas" merupakan susunan struktur untuk menyangga lengkungan kubah tersebut. 


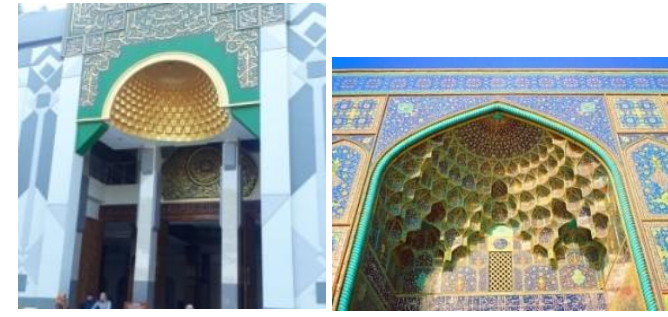

Gambar 14. Ornamen Setengah Kubah Pada Masjid Agung Lamongan Dan Muqarnas Shah Mosque, Isfahan, Iran

Sumber : $\underline{w w w . f l i c k r . c o m}$

Pada bangunan sisi timur ini terdapat kubah, kubah yang ada tidak dominan, dan hanya berfungsi sebagai ornamentasi, kubah yang ada di Masjid Agung Lamongan lebih dekat dengan langgam kubah Indo-persiani, kubah adaptasi dari arsitektur Phustun-persia, yang terpengaruh oleh arsitektur India (mughal) dan menghasilkan langgam baru. Ciri dari kubah ini berbentuk seperti bawang dan terdapat kubah utama yang disertai dengan anak - anak kubah yang ditempatkan berkeliling sepanjang atap atau kubah utama, hal tersebut bisa dilihat pada bangunan Pearl Mosque di Agra, India.
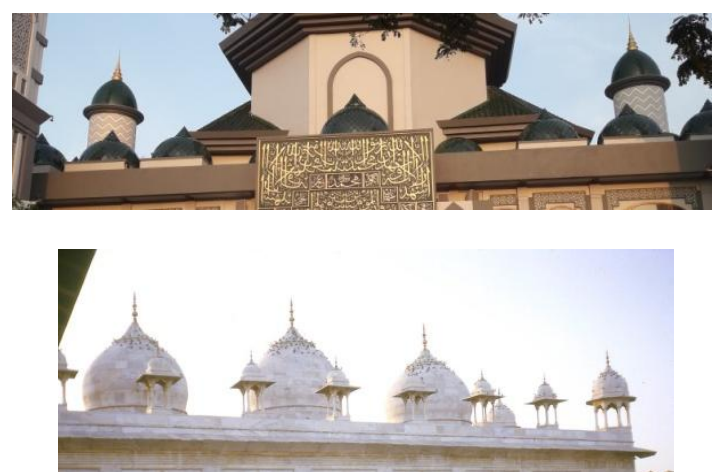

Gambar 15. Kubah Indo-persiani berupa anakanak kubah di sekitar atap

Sumber : www.flickr.com

Ket :

Atas : Masjid Agung Lamongan,

Bawah: Pearl Mosque di Agra, India

\section{KESIMPULAN}

Transformasi fisik pada Masjid Agung Lamongan ini menandakan bahwa adanya fleksisbilitas dalam bentuk arsitektur Masjid, tidak ada aturan baku dalam menentukan bentukan fasad Masjid. Budaya dan keragaman dalam masyarakat jika tidak bertentangan dengan kaidah, syariat dan nilai ketauhidan bisa di akulturasikan dalam bentukan arsitektur Masjid, sehingga menciptakan langgam yang dinamis, selaras dan kekinian dalam menghadapi perkembangan jaman tanpa meninggalkan nilai-nilai keilahian.

\section{PUSTAKA}

A'yun, Qurrota. 2015. Transformasi Bentuk Fisik pada Tipologi Fasade Masjid Jami' Malang. EMARA Indonesian Journal of Architecture. Vol 1 Nomor 2 - Desember 2015

Agustapraja, Hammam Rofiqi. 2018. Pelestarian Arsitektur Langgar Dhuwur Mbah Yai Mastur Lamongan. Jurnal Teknika. Vol 10 hal 10501055

Antariksa. 2011. Metode Pelestarian Arsitektur. www.academia.edu

Amarullah, Mohammad., Dkk. 2014. TipologiMorfologi Arsitektur Rumah Tinggal Masyarakat Nahdliyin Di Kawasan Gang Masjid Singosari. SEMINAR NASIONAL ARSITEKTUR PERTAHANAN (ARSHAN) 2014. Insting Teritorial dan Ruang Pertahanan. Program Studi Arsitektur, UPN "Veteran" Jatim.

Fanani, Achmad Ir. 2009. Arsitektur Masjid. Mizan Media Utama. Bandung

https://suaranasional.com/2018/11/30/aspekkesejarahan-masjid-agung-lamongan/

https://www.dekoruma.com/artikel/69708/arsitektu r-masjid-terindah-di-dunia

https://kontraktorkubahmasjid.com/blog-2/page/11/ https://ndiray.wordpress.com/nabi-muhammadsaw-kota-madinah-jabal-uhud-masjid-qubamasjid-jum\%E2\%80\%99ah-masjid-kiblatainmasjid-sahabat-bir-\%E2\%80\%98ali/

https://tiatimki.wordpress.com/category/foto/page/4 I

https://id.pinterest.com/pin/166633254937129636/

https://www.flickr.com/photos/22955235@N00/39 $\underline{6324975}$

https://www.flickr.com/photos/east_med_wanderer /1471967082

Rochym, Abdul. 1983. Sejarah Arsitektur Islam : Sebuah Tinjauan. PT. Angkasa, Bandung.

Setyabudi, Irawan, dkk. 2012. Tipologi dan Morfologi Arsitektur Rumah Jengki di Kota Malang dan Lawang. arsitektur e-Journal. Volume 5 Nomor 321, Maret.

Sumalyo, Yulianto. 2001. Arsitektur Mesjid dan Monumen Sejarah Muslim. Gadjah Mada University Press

Tugiyono, dkk. 2001. Peninggalan Situs dan Bangunan Bercorak Islam di Indonesia. PT. Mutiara Sumber Widya. Jakarta

Wafiyyah, Siti Kulashatul. 2017. Perkembangan Arsitektur Masjid Agung Lamongan. fakultas adab dan humaniora, Universitas Islam Negeri Sunan Ampel Surabaya.

Wismantara, Pudji Pratitis. 2016. Masjid Agung Jami' Malang dan Ambiguitas Arsitektural . Prosiding Temu Ilmiah IPLBI 2016. 